\title{
Study of Microbial Contaminationin Dental Unit Water Line: A Clinical Implication
}

\author{
*Abdul Azim Asy Abdul Aziz ${ }^{1}$,Siti Najwabinti Hasnan ${ }^{1}$, \\ Syifakmawaddah Abdul Jamil ${ }^{1}$,A. Hamid Mohamad ${ }^{1}$, \\ Syatirah Abdullah ${ }^{1}$, Aspalilah Alias ${ }^{1,2}$ \\ ${ }^{1}$ Faculty Of Dentistry, Universitisains Islam Malaysia \\ ${ }^{2}$ Forensic Unit, Department Of Pathology, Faculty Of Medicine,Universitikebangsaan Malaysia
}

\begin{abstract}
Effective infection control is very crucial. The objective of this research is to determine the level of bacterial countin water from dental chair unit output at the Dental Clinic Faculty of Dentistry, UniversitiSains Islam Malaysia. Five dental chair units of treatment rooms were selected. A total of 31 water samples collected from three-way syringe and cup filler water. Positive control was taken from aquarium and distilled water was used as negative control. The nutrient agar was prepared and the samples were cultured immediately in the laboratory. The samples were incubated for 24 hours in $37^{\circ} \mathrm{C}$ before observation and the total bacteria counting done. Direct counting method was done in three times by calculating all colonies formed unit in 1 millilitre. The

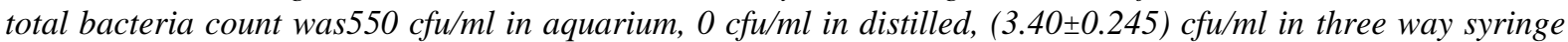
and $(3.75 \pm 0.25) \mathrm{cful} / \mathrm{ml}$ in cup filler water. All samples from five dental units showed less than $200 \mathrm{cfu} / \mathrm{ml}$ of total bacteria count and meet the American Dental Association recommendation. The Gram staining showed that the colonies of bacteria taken from the samples mostly gram negative bacteria. For conclusion, the filter system and anti-retraction valve used in these five dental units is effective but this system must be timely monitor.
\end{abstract}

Keywords: Infection control; Gram stain; water microbiology; biofilms; dental pathogens

\section{Introduction}

Patient's and clinician's wellbeing are major concern during dental treatment. This is because of the exposure to incidents, infectious disease, and radiation[1]. In dentistry, dental unit water line (DUWL) can be a potentially risk to human health because of the nature of the DUWL that contains microorganism. The perceived threat to public health from DUWL contamination comes from opportunistic and respiratory pathogens such as Legionella sp., Mycobacteria sp. and Pseudomonas sp[2].The quality of water from DUWL is important during treatment to minimize any biological exposure as dental units regularly generate aerosols [3-4].

Distilled water and tap water were two water sources that used in the dental chair unit. However, a few studies have reported that most of DUWL in dental chairs is supplied by tap water[5]. The contamination of DUWL is usually caused by microorganismthat formed a layer of biofilm inside the DUWL system[6].Theoretically, detachment of microorganisms from DUWL biofilm which flushed into the oral cavity could infect the patient by indirect transmission of bacteria from dental water through ingestion and inhalation of the aerosol[7]. This problem exists because of the tendency for microorganism to adhere to the walls of the small tube. This will lead to formation of biofilm and if it continues to grow, it can break and enter the patient's oral cavity [8].

DUWL generates bioaerosol during dental treatment which can be a potential source of indirect infection to dental health professionals [9]. Apart from that, the contaminated DUWL can cause cross-infection to the patient[5]. Bacterial contamination of DUWL was first reported and discussed in the literature nearly 50 years agosince DUWL is ideal environment for the growth of microorganisms entering dental units from the tap water supply [10]. Pankhurst stated that most of the microorganism are harmless and cannot cause diseases to human but some of them can be opportunistic pathogens [2]. A study from Depaola et al mentioned that inside the biofilm there are 32 different bacteria, 6 different types of fungi, and 2 types of protozoa have been isolated from dental water [11]. Two reports also stated that most of the bacteria isolated from DUWL are gram negative bacteria which can produce endotoxin such as Pseudomonas aeruginosa sp. and Legionella pneumophillasp. [1213].

The present study was performed to determine to the level of bacterial contamination from dental chair unit output water in the Dental Clinic Faculty of Dentistry, UniversitiSains Islam Malaysia. The results of this study can be added as a support document for waterline treatment. A well-designed water quality indicator should be put in dental unit setting for monitoring. 


\section{Material And Methods}

This study was conducted at Dental Clinic, Faculty of Dentistry (FoD), UniversitiSains Islam Malaysia (USIM). The water samples were taken from five units of dental chair unit from specialist rooms. The samples then were tested using a modified method from the Ma et al [3].

\section{Preparation of the samples}

The water samples were taken from three-way syringe(sterile water) and cup filler (tap water) of each dental unit in three times.Positive control was taken from nearby aquarium and distilled water was used as negative control.

\section{Preparation of nutrient agar}

31 plates of the nutrient agar (Oxoid, England) were prepared. The agar was measured and dissolved in one litre distilled water. After autoclaved at $125^{\circ} \mathrm{C}$, the agar mixture then poured into 32 Petri dishes and left to cool down and solidify [15].

\section{Total bacteria count}

\section{Samples were divided into four groups;}

a. Group 1- positive control (water was taken from aquarium)-1 plate

b. Group 2- negative control (water was taken from)-1 plate

c. Group 3-three-way syringe water -14 plates

d. Group 4-cup filler water- 15 plates

Aseptic technique was used throughout the processes. $1 \mathrm{ml}$ of each sample was added onto the agar and spread using three sector streak technique [16]. The samples then were left overnight to incubate (Memmert, Ine 500 , Germany) at $37^{\circ} \mathrm{C}$ before total bacteria counting.

\section{Gram stain examination}

Gram stain was done to identify the type of bacteria in the colony. A colony of each plate was isolated and used for gram staining. A thin smear of the colony was made on a glass slide and fixed. The smear was covered with crystal violet and incubated for one minute. The slide then was tilted to drain excess crystal violet. The smear was covered with Lugol's iodine for another minute. Decolourization step was done with acetoneiodine for 5 to 10 seconds. The slide was rinsed with water to stop the action of alcohol and flooded with safranin for 30 seconds afterward. The slide was washed under indirect stream of tap water until no colour appeared in the effluent. Then, it was blotted dry. The slide was examined under light microscope (Leica, Germany).

\section{Results}

Total bacteria count was done by counting all the colonies formed unit (cfu) in 1 millilitre (ml) on the plate. Three reading was done to ensure the accuracy. The mean and standard error mean from two sources which were three-way syringe and cup filler are $(3.40 \pm 0.245) \mathrm{cfu} / \mathrm{ml}$ and $(3.75 \pm 0.250) \mathrm{cfu} / \mathrm{ml}$ respectively. Positive control showed total bacteria count was $550 \mathrm{cfu} / \mathrm{ml}$ and negative sample had zero colonies. This result showed that the dental chair units in these five rooms are following the recommendation of American Dental Association (ADA) [17]. (Figure 1)

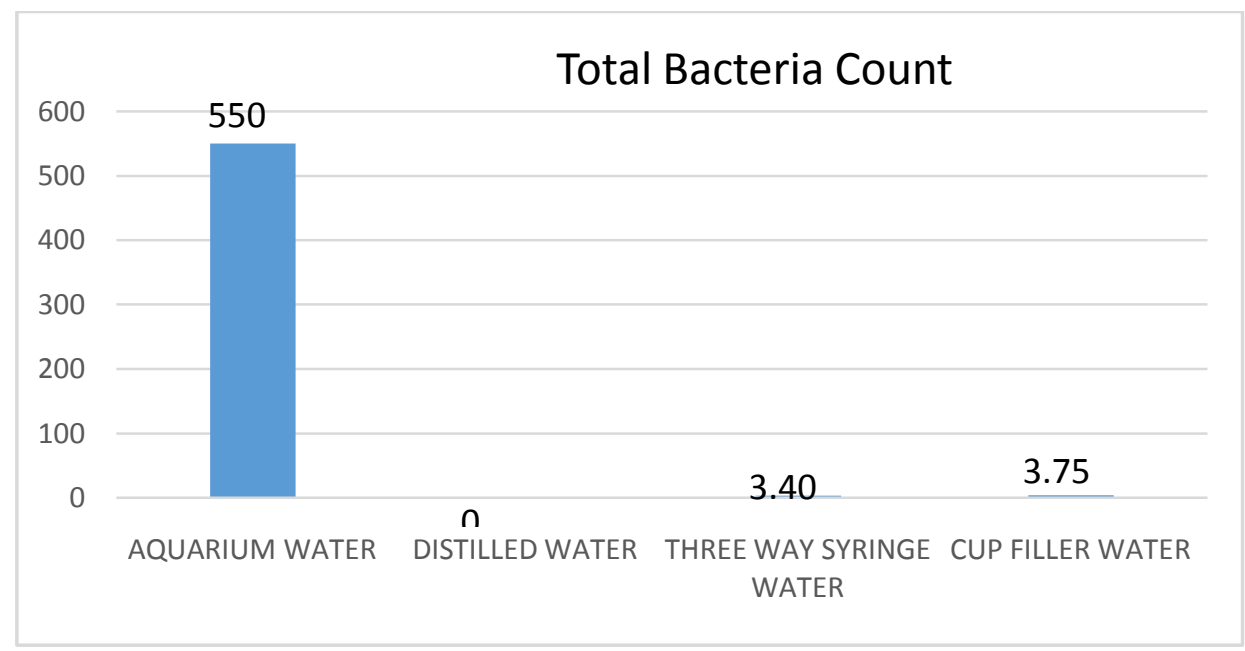

Figure 1 : The mean of total bacteria count in 4 types of water 
Figure 2 shows the mixture of gram positive (blue) and gram negative (pink) bacteria in the aquarium water sample (positive control). Gram staining of colonies from the agar shows a predominance of gram negative bacteria in the sample as shown in figure 3.

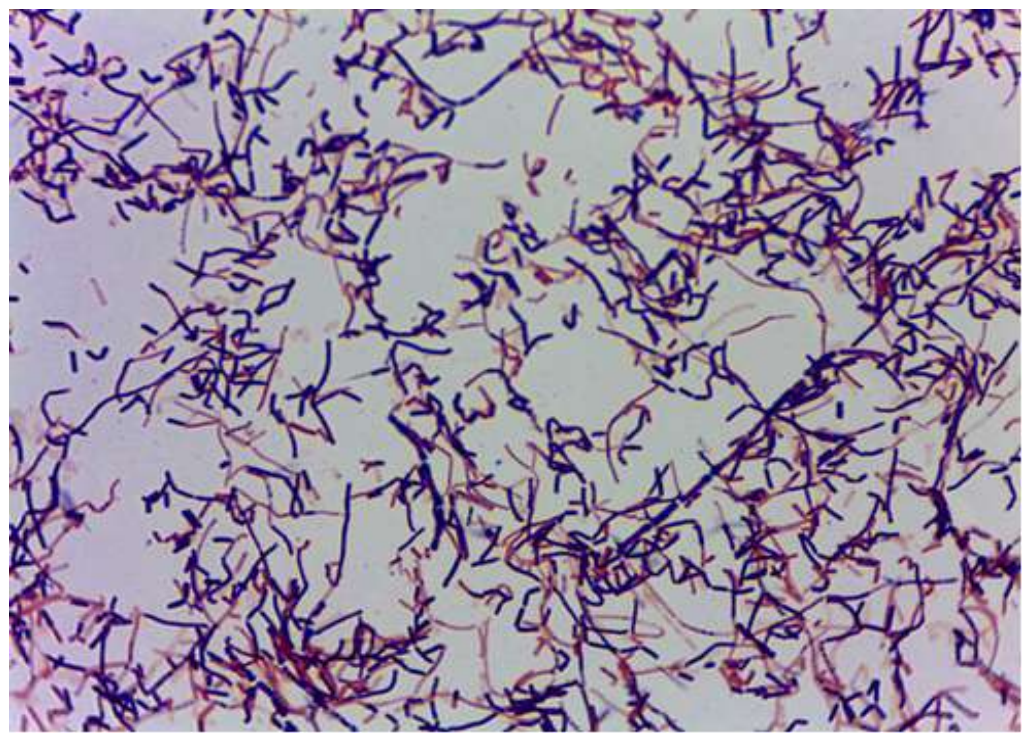

Figure 2: . Plate Positive Control show mixes of gram negative and positive bacteria

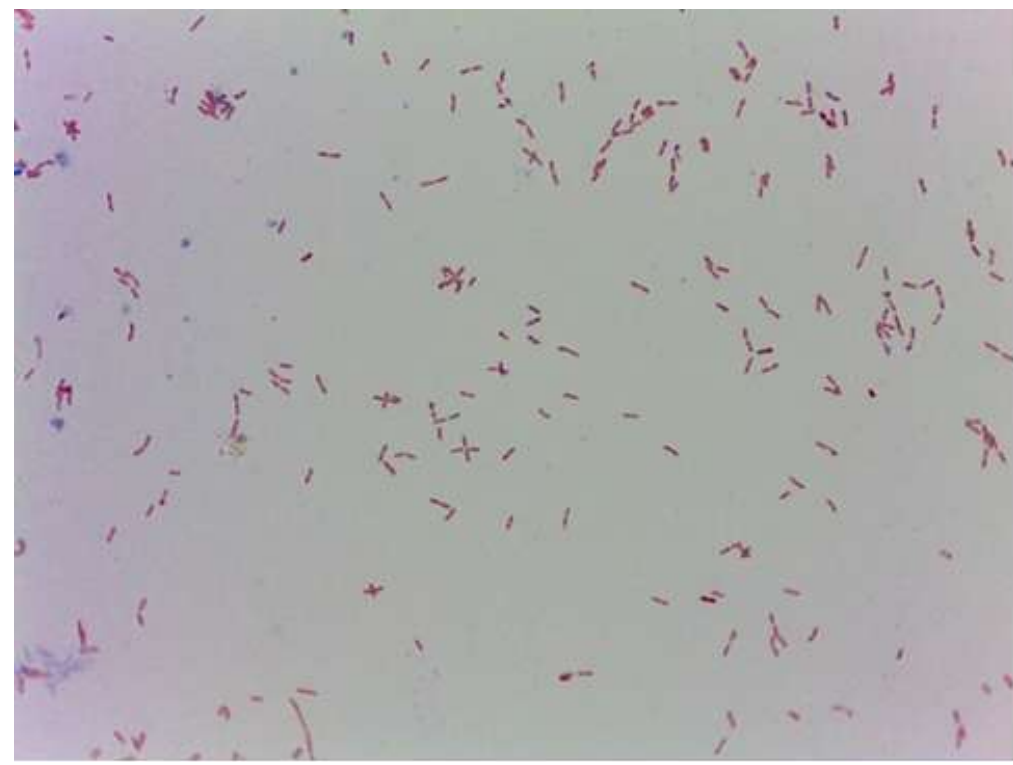

Figure 3: This plate show gram negative rods bacteria in tap water

\section{Discussion}

Recent technology in dental unit manufacture is aiming to reduce DUWL contamination concentrate on two aspects, which are treatment of dental water and improvement of dental unit design. This includes antiretraction valve, filtration system and chemical disinfectants [11].From the finding, all the samples have less than $200 \mathrm{cfu} / \mathrm{ml}$ except for positive control. This result illustrated that DUWL in FoD USIM correspond to ADA submission by having these three methods mentioned above.

Barbeau et al proved that lacking of anti-retraction valve can cause patient's saliva being sucked back into the waterlines [16]. One of the recommendation from Centers for Disease Control and Prevention for preventive measure is by using an appropriate method and equipment in dental chair to maintain the quality of dental water [18]. The DUWL can cause harm to patient if it not properly managed and routinely checked. Retraction is the action that occurs when a water relay within the dental unit shuts off and draws water back into the device. It is bad because if the level of retraction is high enough, the backflow from the oral cavity might happen and contaminated the DUWL. So, from the Guide, anti-retraction valve installed in A-dec Systems is to 
ensure the water flow in one direction. Filtration system also in use to filtrate the unwanted particles especially biofilms [14]

There was a case in 2011 where 82-year-old lady died in Italy because of Legionnaires' disease which she acquired after receiving dental treatment. The source of infection was said most probably from the aerosolized water from the high speed turbine [19]. Although the number of cases are not published widely and the effect of exposure from the DUWL is limited, but there is medico-legal requirement to comply with potable water standards and to confirm to public perception on water safety [20].

The gram negative bacteria prevailed the bacteria community of the sample. This finding correlates to the study done by Pankhurst et al[3]. However, since there was no further test done to key out the bacteria species, we cannot explain the detail of the bacteria pathogenecity. The colony formed on the plates were generally round to oval in shape while the colour were whitish to light yellowish. These are shown in figure 3 . The figure 3 also showed most of the colony formed were single colony that can be easily observed.The results actually met the National Standard of Drinking Water Quality by the Minstry of Health Malaysia recommenation which is less than $500 \mathrm{cfu} / \mathrm{ml}$ [21]. So, it is not only safe to use in dental treatment but also for drinking.

In order to reduce DUWL contamination, here are some recommendation methods such as flushing, monitoring the DUWL quality, peroxide, independent clean water system and using biocides or chemical disinfectants [3]. Those methods concentrate on dental unit design and treatment of dental water.Besides, the other recommendations are follow manufacturer's directions for monitoring water quality and discharge water and air for a minimum of 20 to 30 seconds after each patient from any dental device connected to the water system. Also, consult with the manufacturer on the need for periodic maintenance of antiretraction mechanisms [6]

\section{Conclusion}

In conclusion, the dental unit water line in FoD, USIMfollows the ADA regulation and are safe to be used to the patient. Regular study must be done to check the quality of the water system. Further research may need to expand on identify types of bacteria formed from the samples.

\section{References}

[1]. Peter A.L,Ureporn K, Derek R. S. Occupational Health Problems in Modern Dentistry: A Review. Industrial Health 2007; 45: 611621.

[2]. Caroline L Pankhurst. Risk Assessment of Dental Unit Waterline Contamination. Oral Microbiology And Primary Dental Care. 2003;10(1):5-10

[3]. Ma Mei Siang, ZaliniYunus, Zukri Ahmad. The microbiological quality of water from dental unit waterlines in Malaysian Armed Forces dental centres : The Journal of the School of Dental Sciences UniversitiSains Malaysia 2012; 7(1): 7.

[4]. Liaqat I, Sabri AN (Biofilm, dental unit water line and its control. Afr JClinExperMicrobiol2011; 12(1): 15-21.

[5]. Williams, J. F., N. Andrews, and J. I. Santiago. . Microbial contamination of dental unit waterlines: current preventive measures and emerging options. Compend. Cont. Ed. Dent. 1996; 17: 691-694.

[6]. Global Dental News ; Global Dental Sales and Service : 2010 [ updated: 2010 ; cited : November 2012]. Available from : http://www.globaldental.ca/GD_Flyer.pdf

[7]. CarollneL.Pankhurst, NW Johnson. Microbial Contamination of Dental Unit:The Scientific Argument. -Holmes J. Dental Unit Water Lines- A Review of The Problem \& Solutions. IDJ. 2007; 48 (359-368): 6

[8]. Holmes J. Dental Unit Water Lines- A Review of The Problem \& Solutions. 2007 Feb.

[9]. Szymanska J, Dutkiewicz J. Concentration and species composition of aerobic and facutatively anaerobic bacteria released to the air of a dental operation area before and after disinfection of dental unit waterlines. Int Dent J 2008; 54(6): 438-444

[10]. Blake GC The incidence and control of bacterial infection of dental units and ultrasonic scalers. Br Dent J. 1963; 115: 413-416.

[11]. Depaola, L. G., Mangan, D., Mills, S. E., Costerton, W., Bareau, J., \& Shearer, B. et al. September.A review of the science regarding dental unit waterlines. JADA, 2002; 133: 1199-1206.

[12]. Atlas RM, Williams JF, Huntington MK (Legionella contamination of dental- unit waters. Appl Environ Microbiol, 1995; 61(4): 1208-1213.

[13]. Barbeau J, Tanguay R, Faucher E, Avezard C, Trudel L, Côté L, Prévost AP Multiparametric analysis of waterline contamiantion in dental units. Appl Environ Microbiol. 1996;62(11): 3954-3959.

[14]. Gephardt et al, 1981, Feedback from ASMCUE participants, ASMCUE, 2005.

[15]. Tips for Pouring and Storing Agar Plates: Department of Biology, University of Missouri- St Louis ;1999 [cited 29 Nov 2012] Available from: http://www.umsl.edu/ microbes/tipsforplates.pdf

[16]. Streak Plate Method; Amrita VishwaVidyapeetham University:1956 [updated:2012 ;cited : November 2012]. Available from : http://amrita.vlab.co.in/?sub=3\&brch=73\&sim=213\&cnt=2

[17]. American Dental Association (ADA) Dental unit waterlines: approaching the year 2000. ADA Council on Scientific Affairs. J Am Dent Assoc. 1999; 130(11): 1653-1664.

[18]. Centers for Disease Control and Prevention. Guidelines for Infection Control in Dental Health-Care Settings 2003. MMWR 2003; 52(17): 28-30

[19]. Maria LR, Stefano F, Federica P, Emanuela F, Maria FP, Paolo F, et. al.. Pneumonia associated with a dental unit waterline. The Lancet. 2012; 379: 684 .

[20]. Sehulster L,Chinn RY; CDC; HICPAC Guidelines for environmental infection control in healthcare facilities. Recommendationsof CDC and the Healthcare Infection Control Practices Advisory Committee (HICPAC) MMWRRecomm Rep. 2003; 52(10): 1-42.

[21]. Engineering Services Division ;National Standard for Drinking Water Quality; Second Version, January 2004 